\title{
JENIS-JENIS PUTUSAN HAKIM DALAM PERKARA PIDANA (SUATU CATATAN TENTANG PEMBARUAN KUHAP)
}

\author{
M. Hamdan'
}

\section{Abstrak}

Kinds of judgements in criminal case regulated and formulated in Act No.8/1981 (criminal procedure code), that is judgement of convict, judgement of acquittal judgement or judgement of justification. That judgement will be changed. The change is formulated in Act Draft about Criminal Procedur Code year 2009 (RUU HAP). The three of judgements in that draft are not right because of (1) no sanction without fault principle, (2) in appropriate with subjective and objective sentence of criminal perpetration, (3) inappropriate with no criminal between justification reason and excuse reason doctrine in acquittal judgement and justification judgement.

Kata Kunci: perubahan rumusan putusan hakim.

\section{Pendahuluan}

KUHAP yang merupakan karya agung pada tahun 1981, sekarang ini dirasakan sudah tidak sesuai lagi, sehubungan dengan beberapa konvensi internasional yang berkaitan langsung dengan hukum acara pidana telah diratifikasi, oleh karena itu perlu diperbarui. Pembaruan hukum acara pidana ini juga dimaksudkan untuk lebih memberikan kepastian hukum dan ketertiban hukum bagi masyarakat. ${ }^{2}$ Pembaruan KUHAP tersebut sudah dilaksanakan dalam bentuk draf Rancangan Undang-undang Tentang Hukum Acara Pidana (RUU HAP) Tahun 2009, dan termasuk sebagai salah satu Program Legislasi Nasional (Prolegnas) Tahun 2010. Salah satu pembaruan yang terdapat dalam Rancangan ini adalah tentang jenis-jenis putusan hakim, sebagaimana yang terdapat dalam Pasal 187 RUU HAP. ${ }^{3}$

I Staf Pengajar di Bagian Hukum Pidana Fakultas Hukum Universitas Sumatera Utara. Alamat kontak: hamdan_aldi (ayahoo.com.

${ }^{2}$ Lihat pertimbangan RUU HAP Tahun 2009 huruf $\mathrm{c}$ dan d. 


\section{Pasal 187 RUU HAP berbunyi:}

(1) jika hakim berpendapat bahwa hasil pemeriksaan di sidang tindak pidana yang didakwakan terbukti secara sah dan meyakinkan, maka terdakwa dipidana.

(2) jika hakim berpendapat bahwa hasil pemeriksaan di sidang tindak pidana yang didakwakan tidak terbukti secara sah dan meyakinkan, terdakwa diputus bebas.

(3) Jika hakim berpendapat bahwa perbuatan yang didakwakan kepada terdakwa terbukti, tetapi ada dasar peniadaan pidana, terdakwa diputus lepas dari segala tuntutan hukum.

Dari rumusan Pasal 187 RUU HAP tersebut di atas, menurut penulis ada beberapa masalah yang menarik untuk dianalisis berdasarkan asas-asas, teori maupun pendapat para ahli dalam bidang hukum (pidana) khususnya.

\section{Permasalahan}

Masalahnya adalah, apakah jenis-jenis putusan yag dirumuskan dalam Pasal 187 RUU HAP seperti tersebut di atas sudah sesuai dan berdasarkan asas-asas, teori maupun doktrin yang ada selama ini dalam hukum pidana. Hal inilah yang akan diuraikan dalam tulisan ini sebagai catatan, sumbang saran dalam rangka penyusunan RUU HAP tersebut menjadi Undangundang. Penulis merasa hal ini penting, agar pembaruan KUHAP yang dilakukan ini tidak bertentangan dengan asas-asas, teori maupun doktrin dalam rangka menciptakan Undang-undang yang tidak hanya memberikan

${ }^{3}$ Selama ini jenis-jenis putusan disebut dengan putusan pengadilan (bukan putusan hakim) sebagaiman yang terdapat dalam KUHAP (Undang-undang No.8 Tahun 1981, yang terdiri dari:

a. Putusan pemidanaan sebagaimana yang dirumuskan dalam Pasal 193 KUHAP yang berbunyi: "jika pengadilan berpendapat bahwa terdakwa bersalah melakukan tindak pidana yang didakwakan kepadanya, maka pengadilan menjatuhkan pidana".

b. Putusan bebas sebagaimana yang dirumuskan dalam Pasal 191 ayat (1) KUHAP yang berbunyi: "jika pengadilan berpendapat bahwa dari hasil pemeriksaan di sidang, kesalahan terdakwa atas perbuatan yang didakwakan kepadanya tidak terbukti secara sah dan meyakinkan, maka terdakwa diputus bebas".

c. Putusan lepas dari segala tuntutan sebagaimana yang dirumuskan dalam Pasal 191 ayat (2) KUHAP yang berbunyi: "jika pengadilan berpendapat bahwa perbuatan yang didakwakan kepada terdakwa terbukti, tetapi perbuatan itu tidak merupakan suatu tindak pidana, maka terdakwa diputus lepas dari segala tuntutan hukum". 
kepastian hukum dan ketertiban dalam masyarakat, akan tetapi juga harus taat asas, dan berdasarkan teori serta sinkronisasi (keharmonisan) antara satu peraturan dengan peraturan perundang-undangan lainnya.

\section{Pembahasan}

Pembahasan tentang pembaruan KUHAP ini, adalah merupakan suatu catatan kecil dari sekian banyak pembaruan yang dilakukan dalam RUU HAP, yaitu tentang perumusan bunyi putusan hakim yang terdapat dalam Pasal 187 RUU HAP yang didasarkan kepada tiga hal. Ketiga hal tersebut adalah tentang asas kesalahan, teori yang berkaitan dengan unsur-unsur tindak pidana, dan doktrin tentang alasan penghapus pidana.

\section{A. Asas Tiada Pidana Tanpa Kesalahan}

Asas ini dalam bahasa Belanda dikenal dengan istilah "geen straf zonder schuld", yang menjadi dasar dari baik hukum positif maupun teori ${ }^{4}$. Asas ini adalah asas mutlak yang harus dihormati dalam putusan hakim. Hakim tidak boleh menjatuhkan pidana kepada siapa saja (terdakwa) yang melakukan tindak pidana, jika orang tersebut tidak mempunyai kesalahan. Laksana sebuah gedung bertumpu pada fundamennya, demikian juga pidana bertumpu pada kesalahan. Karena kesalahan, pidana menjadi sah. Dengan perkataan lain: kesalahan - adalah dasar yang mensahkan pidana. ${ }^{5}$ Dengan demikian apabila putusan pemidanaan itu tidak didasarkan pada kesalahan, maka putusan pemidanaan tersebut tidak sah. Asas kesalahan ini juga secara jelas diatur dalam Pasal 6 ayat (2) Undang-undang No.4 Tahun 2004 tentang Kekuasaan Kehakiman. ${ }^{6}$

Jika diperhatikan bunyi putusan yang dirumuskan dalam Pasal 187 ayat (1) RUU HAP, jelas rumusan ini tidak tepat, karena bertentangan dengan asas kesalahan seperti tersebut di atas. Pasal 187 ayat (1) RUU HAP berbunyi: "jika hakim berpendapat bahwa hasil

${ }^{4}$ Utrecht, "Hukum Pidana I", (Bandung: Penerbit Universitas, 1960), hal. 254.

'5chaffmeister, "Hukum Pidana", (Yokyakarta: Liberty, 1995), hal. 83.

- Pasal 6 (2) Undang-undang No.4/2004 berbunyi: "Tidak seorang pun dapat dijatuhi pidana, kecuali apabila pengadilan, karena alat pembuktian yang sah menurut undangundang, mendapat keyakinan bahwa seseorang yang dianggap dapat bertanggungjawab, telah bersalah atas perbuatan yang didakwakan atas dirinya". 


\section{pemeriksaan di sidang tindak pidana yang didakwakan terbukti} secara sah dan meyakinkan, maka terdakwa dipidana" (cetak tebal dari penulis). Dari bunyi pasal ini jelaslah bahwa putusan pemidanaan itu dijatuhkan hakim, apabila tindak pidana yang didakwakan telah terbukti. Dengan demikian RUU HAP hanya menekankan pada terbuktinya tindak pidana, tanpa melihat kepada kesalahan pelaku tindak pidana. RUU HAP seolah-olah ingin menyatakan bahwa begitu seorang terdakwa terbukti melakukan tindak pidana, maka tindak pidana tersebut dapat dicelakan/dipertanggungjawabkan kepadanya; oleh karena itu terdakwa dipidana. RUU HAP dalam menjatuhkan pidana hanya berpandangan, berdasarkan pada apa yang dilakukan (daad-straaf) tanpa memperhatikan pelaku (dader-straaf). Dengan kata lain pembuat RUU HAP cenderung menganut aliran klasik dalam hal pemidanaan ${ }^{7}$ dan aliran monistis dalam hal syarat menjatuhkan pidana, ${ }^{8}$ yang menurut penulis tidak sesuai dan tidak tepat untuk dipertahankan. Hal ini penulis sampaikan, oleh karena jika diperhatikan bunyi Pasal 187 ayat (1) RUU HAP, maka apabila seseorang (terdakwa) telah terbukti melakukan tindak pidana, ia akan dipidana, meskipun kemungkinan orang tersebut tidak mempunyai kesalahan sama sekali. Perumusan seperti ini tentunya sangat bertentangan dengan asas kesalahan dan praktek dunia Pengadilan/putusan hakim (yurisprudensi) selama ini, baik di Indonesia maupun di Belanda (ingat tentang "avas" dalam Arrest H.R. tgl. 14 Pebruari 1916; Water en Melk arrest).

${ }^{7}$ Aliran klasik dalam hal pemidanaan pada prinsipnya berpendapat bahwa pidana harus sesuai dengan perbuatannya (let the punishmernt fit the crime). Sebaliknya aliran modern dan neo-klasik berpendapat bahwa pidana harus sesuai dengan pelaku tindak pidana (let the punishmernt fit the criminal). Lihat Muladi dan Barda Nawawi Arief. "Teori-teori dan Kebijakan Pidana", (Bandung: Alumni, 1984), hal. 61-63. Muladi, "Lembaga Pidana Bersyarat", (Bandung: Alumni, 1985), hal. 42-43.

${ }^{8}$ Aliran monistis dalam hal syarat untuk menjatuhkan pidana berpendapat bawa, pada prinsipnya orang dapat dipidana apabila melakukan tindak pidana. Aliran ini berpendapat bahwa antara perbuatan dengan pertanggungjawaban pidana merupakan satu kesatuan. Sebaliknya aliran dualistis berpendapat bahwa antara perbuatan pidana dengan pertanggungjawaban pidana, merupakan dua hal yang berbeda (dipisahkan). Lihat Sudarto, "Hukum Pidana I", (Semarang: Yayasan Sudarto, 1990), hal.40. A.Z.Abidin, Bunga Rampai "Hukum Pidana", (Jakarta: Pradnya Paramita, 1983), hal.47-48. A. Zainal Abidin Farid, "Hukum Pidana I", (Jakarta: Sinar Grafika, 1995), hal.43-44. Roeslan Saleh, "Perbuatan dan Pertanggungjawaban Pidana Dua Pengertian Dasar dalam Hukum Pidana", (Jakarta: Aksara, 1983), hal. 75-79. 
Rumusan Pasal 187 ayat (1) RUU HAP ini juga ternyata tidak lebih baik dari Pasal 193 KUHAP yang mau diperbarui. Dibandingkan dengan Pasal 193 KUHAP yang mengatur tentang putusan pemidanaan ini, maka Pasal 193 KUHAP adalah lebih baik, oleh karena perumusannya tetap mencantumkan tentang kesalahan terdakwa, disamping tentang tindak pidana yang didakwakan. ${ }^{9}$ Dengan kata lain KUHAP jelas lebih baik perumusannya, karena menganut asas kesalahan, disamping menganut system daad-dader straafrecht dalam hal pemidanaan, yang tetap memperhatikan pada perbuatan dan (kesalahan) pelaku. Selanjutnya jika perumusan RUU HAP ini tetap dipertahankan, hal ini juga bertentangan dengan bunyi Pasal 44 ayat (1) KUHPidana ${ }^{10}$ dan maksud dari Pasal 4 ayat (1) Undang-undang No. 3 Tahun 1997 tentang Pengadilan Anak. ${ }^{11}$ Oleh karena berdasarkan kedua pasal tersebut maka orang gila dan anak yang berumur dibawah 8 tahun, tidak dapat dipidana. Sedangkan menurut Pasal 187 ayat (1) RUU HAP hakim akan menjatuhkan pidana kepada merka itu (yang sesungguhnya tidak dapat dipertanggungjawabkan) karena terbukti secara sah dan meyakinkan melakukan tindak pidana, meskipun sebenarnya menurut Undang-undang Pengadilan Anak dan KUHP merka tidak dapat dipidana. Dengan kata lain penyusunan RUU HAP tidak memperhatikan harmonisasinya dengan peraturan perundang-undangan yang lain (antara hukum pidana formil dengan hukum pidana materiel tidak sinkron/harmonis).

\section{B. Unsur-unsur Tindak Pidana}

Dalam hukum pidana seseorang dapat dipidana apabila perbuatannya tersebut memenuhi unsur-unsur dari suatu tindak pidana. Dalam teori dikenal ada dua unsur dalam tindak pidana, yaitu unsur

9 Pasal 193 KUHAP berbunyi: "Jika pengadilan berpendapat bahwa terdakwa bersalah melakukan tindak pidana yang didakwakan kepadanya, maka pengadilan menjatuhkan pidana". (cetak tebal dari penulis).

10 Pasal 44 ayat (1) KUHPidana berbunyi:"Barangsiapa mengerjakan sesuatu perbuatan, yang tidak dapat dipertanggungjawabkan kepadanya karena kurang sempurna akalnya atau karena sakit berubah akal tidak boleh dipidana".

${ }^{11}$ Pasal Pasal 4 ayat (1) Undang-undang Pengadilan Anak berbunyi: "Batas umur Anak Nakal yang dapat diajukan ke Sidang Anak adalah sekurang-kurangnya 8 (delapan) tahun tetapi, belum mencapai umur 18 (delapan belas) tahun dan belum pernah kawin". Selanjutnya dalam Penjelasan pasal tersebut disebutkan bahwa anak yang belum mencapai umur 8 (delapan) tahun dianggap belum dapat mempertanggungjawabkan perbuatannya. 
subjektif dan unsur objekif. Unsur subjektif berkaitan dengan keadaan diri pribadi pembuat dan jiwa atau sikap batinnya dalam melakukan perbuatan (sengaja/lalai). Sedangkan unsur objektif berkaitan dengan keadaan di luar diri pribadi pembuat, yaitu perbuatan yang dilakukan, waktu dan tempat tindak pidana serta hal-hal lain berkaitan dengan tindak pidana tersebut. ${ }^{12}$ Dengan demikian seseorang baru dapat dipidana apabila kedua unsur (subjektif dan objektif) tersebut dipenuhi. Kedua unsur tersebut merupakan syarat yang harus dipenuhi untuk adanya putusan pemidanaan. ${ }^{13}$

\section{UNSUR SUBJEKTIF + UNSUR OBJEKTIF $=$ DIPIDANA}

Dengan demikian jika hanya tindak pidana yang didakwakan terbukti (sebagai unsur objektif) tanpa adanya kesalahan (sebagai unsur subjektif), maka syarat untuk menjatuhkan pidana tidak terpenuhi. Berdasarkan hal ini maka rumusan Pasal 187 (1) RUU HAP juga tidak tepat.

\section{Doktrin tentang Alasan Penghapus Pidana}

Alasan penghapus pidana adalah peraturan yang terutama ditujukan kepada hakim. Peraturan ini menetapkan dalam keadaan apa seorang pelaku, yang telah memenuhi perumusan delik yang seharusnya dipidana, tidak dipidana. Hakim menempatkan wewenang. dari pembuat undang-undang untuk menentukan apakah telah terdapat keadaan khusus seperti dirumuskan dalam alasan penghapus pidana. ${ }^{14}$

Menurut doktrin, alasan penghapus pidana itu dapat dibagi dua, yaitu alasan pemaaf yang menghapuskan kesalahan pelaku dan alasan

${ }^{12}$ Lihat Andi Hamzah, "Asas-asas Hukum Pidana", (Jakarta: Rineka Cipta, 1991), hal.81-83. M. Yahya Harahap, "Pembahasan Permasalahan dan Penerapan KUHAP", (Jakarta: Sinar Grafika, 2005), hal. 346. Sedangkan menurut Vrij, disamping itu juga ada unsur subsosial, ialah semacam kerusakan dalam ketertiban hukum. Lihat Sudarto. Op. Cit., hal.48-49.

13 Lihat Abidin. Op.Cit., hal. 47-48. Moeljatno, "Perbuatan Pidana dan Pertanggungjawaban dalam Hukum Pidana", (Jakarta: Bina Aksara, 1983), hal. 23-24. Bandingkan Jan Remmelink, "Hukum Pidana", (Jakarta: Gramedia Pustaka Utama, 2003), hal. 146-147.

${ }^{14}$ M. Hamdan, "Pembaharuan Hukum Tentang Alasan Penghapus Pidana", (Medan: USU Press, 2008), hal.1 mengutip Arnhem E. Ph. R. Sutorius (1988). "Alasan-alasan Penghapus Kesalahan Khusus", Penerjemah Wonosutanto. Bahan Penataran Hukum Pidana Angkatan II. Kerjasama Hukum Indonesia-Belanda. Bandar Lampung: FH Unila. hal. 11. 
pembenar yang menghapuskan sifat melawan hukumnya perbuatan. ${ }^{15}$ Hal ini penulis kemukakan karena selama ini ada kecenderungan dalam praktek yang mencampuradukkan antara alasan pembenar dengan alasan pemaaf, sehingga membawa pegaruh pada putusan hakim yang tidak tepat, yaitu antara putusan bebas dengan putusan lepas dari segala tuntutan hukum, ${ }^{16}$

Kesalahan yang sama juga terlihat dalam rumusan Pasal 187 (2) RUU HAP yang mengatur tentag putusan bebas, dan Pasal 187 ayat (3) RUU HAP yang mengatur tentang putusan lepas dari segala tuntutan hukum.

Pasal 187 (2) RUU HAP dirumuskan:

Jika hakim berpendapat bahwa hasil pemeriksaan di sidang tindak pidana yang didakwakan tidak terbukti secara sah dan meyakinkan, terdakwa diputus bebas.

Pasal 187 (3) RUU HAP dirumuskan:

Jika hakim berpendapat bahwa perbuatan yang didakwakan kepada terdakwa terbukti, tetapi ada dasar peniadaan pidana, terdakwa diputus lepas dari segala tuntutan hukum.

(cetak tebal dari penulis).

Kedua rumusan tentang putusan hakim sebagaimana tersebut di atas, tidak tepat ditinjau dari sudut pandang doktrin. Menurut doktrin, sebenarnya putusan bebas itu disebabkan adanya alasan pembenar yaitu alasan yang menghapuskan sifat melawan hukumnya perbuatan. Sedangkan putusan lepas dari segala tuntutan hukum disebabkan adanya alasan pemaaf, yaitu alasan yang menghapuskan kesalahan pelaku. ${ }^{17}$

Dari bunyi rumusan Pasal 187 ayat (2) tersebut, maka dapat disimpulkan bahwa putusan bebas menurut RUU HAP, hanya

${ }^{15}$ Schaffmeister, Op. Cit., "A Justification speaks to the rightness of the act; an excuse, to whether the actor is accountable for a concededly wrongful act". Fletcher, George P., "Rethinking Criminal Law", (New York: Oxford University Press, 2000), hal. 56-58.

${ }^{16}$ Hamdan. Op. Cit., hal. 21. "In general the courts have tended to mix arguments of justification whit those of excuse whitout noticing the distinction", Andrew Ashworth, "Principle of Criminal Law", (New York: Oxford University Press, 2003), hal. 225.

${ }^{17}$ Lihat Schaffmeister. Op. Cit., hal.148-150. Remmelink. Op. Cit., hal. 209-227. Saleh. Op. Cit., hal. 95-96. Moeljatno.Op.Cit.hal.29-30. Abidin. Op. Cit., hal.48-49. Farid. Op. Cit., hal. 203. 
menekankan atau berkaitan dengan tindak pidana (perbuatan melawan hukum) yang tidak terbukti. Sedangkan menurut doktrin perbuatan melawan hukumnya itu yang dihapuskan. Jadi ada kemungkinan tindak pidananya (perbuatan melawan hukum) terjadi atau terbukti akan tetapi dihapuskan. Hapusnya sifat melawan hukum dari perbuatan tersebut ada yang tertulis dalam undang-undang (KUHP) seperti yang diatur dalam Pasal 49 ayat (1), Pasal 50 dan Pasal 51 ayat (1) KUHP, dan ada yang tidak tertulis, di luar undang-undang seperti hapusnya sifat melawan hukum materiel. ${ }^{18}$ Jadi yang harus dibuktikan hakim itu adalah apakah sifat melawan hukum dari perbuatan terdakwa itu dapat dihapuskan atau tidak, bukan hanya membuktikan terjadinya perbuatan melawan hukum (tindak pidananya). Oleh karena mungkin saja tindak pidananya (perbuatan melawan hukum) terbukti, akan tetapi ada hal-hal yang dapat menghapuskan sifat melawan hukum dari perbuatan terdakwa tersebut, yang menyebabkan ia harus diputus bebas.

Putusan lepas dari segala tuntutan hukum menurut Pasal 187 ayat (3) RUU HAP, apabila perbuatan terdakwa terbukti, tetapi ada dasar peniadaan pidana. Dengan demikian dari bunyi putusan ini dapat disimpulkan bahwa RUU HAP menyatakan bahwa semua alasan peniadaan/penghapus pidana itu akan mengakibatkan putusan lepas dari segala tuntutan hukum. Hal ini tentunya tidak benar. Oleh karena menurut doktrin alasan atau dasar untuk meniadakan pidana itu ada yang menyebabkan putusan bebas dan ada yang menyebabkan putusan lepas dari segala tuntutan hukum. Apabila sifat melawan hukum dari perbuatan itu yang hapus, maka terdakwanya diputus bebas. Sedangkan apabila kesalahan pelaku/terdakwa yang dihapuskan (pelakunya tidak dapat dipertanggungjawabkan) barulah putusan itu berbunyi lepas dari segala tuntutan hukum. Hapusnya kesalahan pelaku/terdakwa tersebut ada yang tertulis dalam undang-undang (KUHP) seperti yang diatur dalam Pasal 44, 48, 49 ayat (2), dan Pasal 51 ayat (2) KUHP, dan ada yang tidak tertulis, di luar undang-undang yaitu hapusnya kesalahan sama sekali (avas=afwezigheid van alle schuld) seperti yang terjadi dalam kasus pengantar susu. Berdasarkan hal ini maka pembuat RUU HAP telah salah merumuskan bunyi

18 Komariah Emong Sapardjaja, "Ajaran Sifat Melawan Hukum Materiel dalam Hukum Pidana Indonesia Studi Kasus tentang Penerapan dan Perkembangannya dalam Yurisprudensi", (Bandung: Alumni, 2002), hal. 51-56. 
putusan lepas dari segala tuntutan, yang seolah-seolah berlaku untuk semua alasan peniadaan pidana.

\section{Penutup}

Dari uraian tersebut di atas, maka menurut penulis jenis-jenis putusan hakim yang dirumuskan dalam Pasal 187 RUU HAP tidak perlu dipertahankan. Oleh karena rumusan tersebut tidak sesuai dengan asas tiada pidana tanpa adanya kesalahan, tidak sesuai dengan teori tentang unsur-unsur tindak pidana, dan tidak sesuai dengan doktrin tentang alasan penghapus pidana.

Berdasarkan hal tersebut di atas, maka jenis-jenis putusan yang dirumuskan dalam Pasal 187 RUU HAP, penulis sarankan sebagai berikut:

1. Putusan Pemidanaan (Pasal 187 ayat (1) RUU HAP) menjadi: "Jika hakim berpendapat bahwa terdakwa bersalah melakukan tindak pidana yang didakwakan kepadanya, maka terdakwa dipidana".

2. Putusan bebas (Pasal 187 (2) RUU HAP) menjadi: "Jika hakim berpendapat bahwa hasil pemeriksaan di sidang kesalahan terdakwa atas tindak pidana yang didakwakan tidak terbukti secara sah dan meyakinkan, atau karena ada alasan pembenar maka terdakwa diputus bebas".

3. Putusan lepas dari segala tuntutan hukum (Pasal 187 (3) RUU HAP) menjadi: "Jika hakim berpendapat bahwa perbuatan yang didakwakan kepada terdakwa terbukti, tetapi tidak merupakan tindak pidana, atau ada alasan pemaaf maka terdakwa diputus lepas dari segala tuntutan hukum". 


\section{Daftar Pustaka}

\section{Buku}

Abidin, Andi Zainal. Bunga Rampai Hukum Pidana. Jakarta: Pradnya Paramita.1982.

Ashhworth, Andrew. Principle of Criminal law. New York: Oxford University Press. 2003.

Farid, A.Zainal Abidin. Hukum Pidana I. Jakarta: Sinar Grafika. 1995.

Fletcher, George P. Rethinking Criminal Law. New York: Oxford University Press. 2000.

Hamdan. M. Pembaharuan Hukum Tentang Alasan Penghapus Pidana. Medan: USU Press. 2008.

Hamzah, Andi. Asas-asas Hukum Pidana. Jakarta: Rineka Cipta. 1991.

Harahap, M. Yahya. Pembahasan Permasalahan dan Penerapan KUHAP

Pemeriksaan Sidang Pengadilan Banding, Kasasi dan Peninjauan Kembali. Jakarta: Sinar Grafika. 2005.

Moeljatno. Perbuatan Pidana dan Pertanggungjawaban dalam Hukum Pidana. Jakarta: Bina Aksara. 1983

Muladi. Lembaga Pidana Bersyarat. Bandung: Alumni. 1985. , dan Barda Nawawi A. Teori-teori dan Kebijakan Pidana. Bandung: Alumni. 1984.

Remmelink, Jan. Hukum Pidana Komentar atas Pasal-Pasal Terpenting dari Kitab Undang-undang Hukum Pidana Belanda dan Padanannya dalam Kitab Undang-undang Hukum Pidana Indonesia. Jakarta: Gramedia Pustaka Utama. 2003.

Saleh, Roeslan. Perbuatan dan Pertanggungjawaban Pidana Dua Pengertian Dasar dalam Hukum Pidana. Jakarta: Aksara Baru. 1983.

Sapardjaja, Komariah Emong. Ajaran Sifat Melawan Hukum Materiel dalam Hukum Pidana Indonesia Studi Kasus tentang Penerapan dan Perkembangannya dalam Yurisprudensi. Bandung: Alumni. 2002.

Schaffmeister, D. Et.al. Hukum Pidana. Yokyakarta: Liberty. 1995.

Sudarto. Hukum Pidana I. Semarang: Yayasan Sudarto FH Undip. 1990. 
515 Jurnal Hukum dan Pembangunan Tahun ke-40 No,4 Oktober-Desember 2010

Utrecht. Hukum Pidana I. Jakarta: Penerbit Universitas. 1960

\section{Rancangan dan Peraturan Perundang-undangan}

Undang-undang No.1/1946 (KUHP)

Undang-undang No.8/1981 (KUHAP)

Undang-Undang No.3/1997.

Undang-Undang No.4/2004

Rancangan UU HAP Tahun 2009 